Acta vet. scand. $1981,22,315-330$.

From the Departments of Virology, Pathology, and Cattle and Sheep Diseases, Faculty of Veterinary Medicine, Swedish University of Agricultural Sciences, and National Veterinary Institute, Uppsala, Sweden.

\title{
VISNA VIRUS MENINGOENCEPHALOMYELITIS IN GOATS
}

\author{
By \\ Bo Sundquist, Lennart Jönsson, Sten-Olof Jacobsson, \\ and Karl-Erik Hammarberg
}

SUNDQUIST, BO, LENNART JÖNSSON, STEN-OLOF JACOBSSON and KARL-ERIK HAMMARBERG: Visna virus meningoencephalomyelitis in goats. Acta vet. scand. 1981, 22, 315-330. - A progressive paresis was encountered in herds of Swedish goats. The symptoms developed during a period of weeks or months, and were initially often seen as a weakness of the hind limbs before the animals became paralytic. The development and the histopathological lesions of the disease in the CNS and the lungs were similar to those of visna in sheep. In vitro grown choroid plexus cells, prepared from affected goats, showed foci of polykaryocytes. Electron microscopy revealed the presence of particles morphologically similar to those of sheep visna virus (SVV). Goats experimentally infected with the goat visna virus (GVV) developed CNS lesions similar to those of visna in sheep and became seropositive to SVV. The results of complement fixation tests, carried out on sera from 11 goat herds, showed a coincidence between seropositiveness and the occurrence of disease in one and the same herd. Using the ELISA method, an average of $80 \%$ of the goats in 5 herds were found to be seropositive to GVV.

visna virus; meningoencephalomyelitis; goat.

Visna is a slowly developing meningoencephalomyelitis in sheep characterized by a prolonged incubation period. The clinical symptoms consist of a paresis of the extensors of the posterior feet, an abnormal position of the head and finally complete paralysis (Sigurdsson et al. 1957, Sigurdsson \& Pálsson 1958). The disease is caused by a virus classified as a retrovirus; the samt virus is also the causative agent of maedi, a progressive interstitial pneumonia in sheep (Haase 1975, Pálsson 1976). The virus is assigned to the type of diseases called slow infections (Sigurdsson 1954). 
In the preceding decade reports were published describing a disease in adult goats which in its clinical and morphological appearance closely resembles visna (Stavrou et al. 1969, Griem $\&$ Weinhold 1975, Hammarberg 1978). Dahme et al. (1973) identified two types of neuropathological changes in goats, namely a granulomatous lesion in periventricular, paraventricular regions and meningeal spaces plus a predominantly demyelinating process close to the ventricular system.

Weinhold (1974) and Weinhold \& Triemer (1978) investigated the disease in goats and found that neutralizing antibodies to the sheep visna virus (SVV) were present in the sera of affected goats. The same authors and, recently, Cork \& Narayan (1980) recognized virus particles characterized as a retrovirus in cultures of choroid plexus cells from sick animals.

During the last 3 years $10-15$ goats per year have been diagnosed by one of the authors (K.-E.H.) as having a slowly progressive paresis. These sick goats were solitary cases in the herds.

The present report describes: (1) the clinical and pathological features of the natural and experimental disease in goats; (2) efforts to identify the agent; and (3) results of a serological study in relation to the spread of infection. The agent is referred to as goat visna virus (GVV).

\section{Goats}

\section{MATERIAL AND METHODS}

The clinical symptoms of 7 paretic goats were studied at the faculty for various periods and then anesthetized with sodium pentobarbital and exsanguinated. The animals were of Swedish landrace, 1-5 years old, and were obtained from the northern and central areas of Sweden. Five additional goats of the same age and with neurological symptoms were slaughtered by the owners. The brains and the cervical sections of the spinal cords were sent for histopathological examination.

Three goat kids, 4 weeks old, of Swedish landrace, were used for experimental infection.

\section{Pathology}

Complete necropsies were performed on goats with natural disease and on experimentally infected goats killed at various 
stages of the disease. Post mortem examination was made of the brain and the cervical cord of 5 additional animals which were slaughtered after showing severe neurological symptoms. All tissues for histopathological examination were fixed in neutral buffered $10 \%$ formalin. Ten blocks were cut from each brain and processed for histopathological examination. Specimens were also taken from 3 different levels of the spinal cord, i.e. the cervical cord and middle of the thoracic and lumbar cord, and from the sciatic nerve on both sides and the optic nerve at its emergence from the ocular bulb on one side. Additional sections of most organs were collected. Histologic sections were stained with hematoxylin-eosin. Special stains used were: Luxol Fast Blue with periodic acid-Schiff (PAS) or cresyl echt violet for myelin; Sudan black for fat; Masson's trichrome and Lendrum's stains for inclusion bodies.

\section{Cell cultures}

The choroid plexus was taken out aseptically from newly killed animals for virus isolation. The choroid plexus (CP) was dissected, prepared, trypsinized and explanted in plastic tissue culture flasks with Eagles' minimal essential medium, $2 \mathrm{mmol} / \mathrm{l}$ gluthamine, $10 \%$ fetal bovine serum and antibiotics as has been described previously (Sundquist \& Larner 1979). After 5 subcultivations the $\mathrm{CP}$ cells were prepared for light and electron microscopy.

The CP cells growing in Nunc Petri dishes were fixed with $2 \%$ glutaraldehyde, post-fixed in $1 \%$ osmium tetroxide, prestained with uranyl acetate and post-stained with lead citrate. They were examined in a Philips RA 201 electron microscope.

\section{Virus}

Confluent sheep CP cells were infected with 5 TCID $_{50} /$ cell SVV. At maximal cytopathic effect the virus in the culture medium was concentrated by centrifugation at $80.000 \times \mathrm{g}$ for 90 min. The virus was repelleted, suspended in phosphate-buffered saline (PBS), disrupted with $0.5 \%$ Triton $\mathrm{X}-100$ and used as an antigen in the immunodiffusion test. In the ELISA, virus without detergent treatment was used. Alternatively, the culture medium was used directly in the complement fixation test (CF). From goat CP cell media GVV was prepared by the same technique as described above. 


\section{Serological tests}

Serological tests were performed on serum samples from 176 goats, representing 11 herds in the northern part of Sweden and from all the animals mentioned above. Complement fixation (CF) and immunodiffusion (ID) tests were performed according to the conventional methods. The ELISA procedure used for the detection of antibodies to the visna virus followed essentially the indirect technique described by Voller et al. (1976). Microtiter plate wells (Cooke® M $129 \mathrm{~A}$ ) were coated with the virus antigen by incubation of the antigen diluted in a carbonate buffer, pH 9.7 for $18 \mathrm{~h}$ at $+4{ }^{\circ} \mathrm{C}$. Before use, the plates were washed thoroughly with water-Tween-80 $(0.05 \%)$ in a homemade washing machine. The goats' sera were diluted $1 / 10$ in PBS, 0.001 mol/1 EDTA, $0.05 \%$ Tween-80. The samples were incubated at $+37^{\circ} \mathrm{C}$ for $2 \mathrm{~h}$, and then washed as before. The peroxidase antigoat immunoglobulin conjugate diluted in PBS, $0.05 \%$ Tween-80 was added to each well and incubated for $1 \mathrm{~h}$ at $+37^{\circ} \mathrm{C}$. The optimal dilution of the conjugate was determined as described by Voller et al. (1976). The plates were then washed as before and the presence of bound conjugate activity was detected by adding 5-aminosalicylic acid $(1 \mathrm{mg} / \mathrm{ml})$ dissolved in $0.05 \mathrm{~mol} / 1$ phosphate buffer $\mathrm{pH}$ 5.9. The plates were incubated for $3 \mathrm{~h}$, and the product was determined by measuring the absorbence in a spectrometer at $492 \mathrm{~nm}$.

\section{Experimental infection}

Goat visna virus was pelleted from a choroid plexus cell culture prepared from an adult, naturally infected goat. The virus was resuspended in $0.14 \mathrm{~mol} / \mathrm{l} \mathrm{NaCl}$ buffer, $\mathrm{pH}$ 7.4. Two kids were inoculated intracerebrally with approximaterly $0.1 \mathrm{ml}$ using the method described for experimental visna virus infection in sheep (Sigurdsson et al. 1957). One kid was inoculated intranasally with $2 \mathrm{hl}$. The animals were then housed in isolation until they were killed 2, 4 and 6 months after the infection, respectively.

\section{Clinical findings}

\section{RESULTS}

The disease was usually insidious in its onset and was found in goats $1-5$ years old with the following general manifestations: 
Lameness or a slight aberration in gait of the hindquarters was one of the first clinical signs. Gradually weakness of the hind limbs became more apparent. Extensor muscles of one or both hind feet weakened and, consequently, the fetlock joints usually flexed more in one foot than in the other during locomotion. Sometimes the animals rested the distal end of the metatarsus and the dorsal surface of the phalanges on the ground when forced to move. Later on, the paresis exacerbated and progressed to paralysis. Nystagmus and trembling of the lips and facial muscles were seen in a few animals. The paresis progressed slowly to the forelegs and neck. The goat then tended to lie down even when eating and rising became difficult. Gradually the animal became paralytic to the point that it could not even rise unaided. The course of the disease from the first clinical signs to the stage of paraplegia or even total paralysis ranged from a few weeks up to several months. The disease sometimes progressed in waves, e.g. it remained in the same stage a few weeks and then exacerbated. The affected goat usually remained alert during a long period of the disease. Fever did not occur, and appetite, circulation, respiration and digestion seemed to be unaffected. The withdrawal reflexes were unaffected in paralytic limbs. According to the farmers, milk production of a sick goat decreased 25-50\%. Because paretic goats were difficult to maintain, they were usually killed before they became recumbent.

For some goats the clinical manifestation of the disease could be described as follows: the sick goat isolated itself from the herd and was unwilling to walk, and it tended to stand with its head lowered and the extremities extended in a "sawhorse" stance. However, it was able to walk, eat and drink. When forced to move the animal pushed against things in its way and missed the watertrough when it wanted to drink. The menace reflex was usually normal. The affected animal was weak and ataxic in its movements but had no lameness or paresis in any special limb. The goat could remain in this stage for weeks or sometimes months until it suddenly died.

All outbreaks of the disease occurred during autumn, winter and early spring months. 
Figure 1. Slight inflammatory reaction of the thalamus with a delicate perivascular cuff of mononuclear cells. There is a small glial nodule on the upper right with destruction of white matter. Luxol Fast Blue-PAS, $\times 80$.

F ig u r e 2. Intense inflammation in the fiber tracts of the medulla oblongata. An irregular central necrosis is surrounded by macrophages and lymphocytes. Hematoxylin-easin, $\times 180$.

Figure 3. Severe malacia with infiltrates of lymphocytes and macrophages in the central white matter of the cerebrum. Wide perivascular accumulations composed of macrophages, lymphocytes and plasma cells are prominent. Hematoxylin-eosin, $\times 180$.

Fig u re 4. Part of the brain stem close to the ventricular system (right): Extensive inflammatory reaction with a necrosis and breakdown of myelin. Perivascular infiltrates extend into adjacent tissue. Hematoxylin-eosin, $\times 60$.

Figure 5. Inflammation around the central canal in the lumbar segment of the spinal cord. Prominent inflammatory and destructive lesions radiate from the central canal. Luxol Fast Blue-PAS, $\times 120$.

Figu re 6. Detail of spinal cord in Figure 7 with severe malacia and perivascular infiltrates. The leptomeninges are infiltrated by mononuclear cells, chiefly lymphocytes (arrow-heads). Hematoxylin-eosin, $\times 140$.

Figure 7. Thoracic spinal cord severely affected by extensive destructions of the white matter. The lesions extend into contiguous grey matter on the right side with loss of myelin and malacia. Wide perivascular cuffs are demonstrated. Only slightly affected blood vessels on the left side. Hematoxylin-eosin, $\times 36$.

Figure 8. Lumbar spinal cord of a goat kid 4 months after experimental intranasal infection. The perivascular infiltrates and malacic lesions are most prominent on the right side. Both the white matter and the grey matter are affected. Hematoxylin-eosin, $\times 36$.

Figure 9. Severe interstitial pneumonia with tatal consolidation of the lung tissue. There is pronounced proliferation of lymphocytes and large mononuclear cells. Hematoxylin-eosin, $\times 115$.

F i g u r e 10. Normal goat choroid plexus cells grown as an orderly array of mononucleated, elongated cells. Giemsa stain, $\times 160$.

F ig u r e 11. Choroid plexus cell culture prepared from a paralysed goat. Multinuclear giant cells have been formed with many nuclei in the central parts of the cells. Giemsa stain, $\times 160$.

Figure 12. Electron micrograph of extracellular virus particle accumulation in choroid plexus cell culture. Both single core particles and particles with translucent centers are visible. $\times 100,000$. 
Bo Sundquist et al.: Visna Virus Meningoencephalomyelitis in Goats.

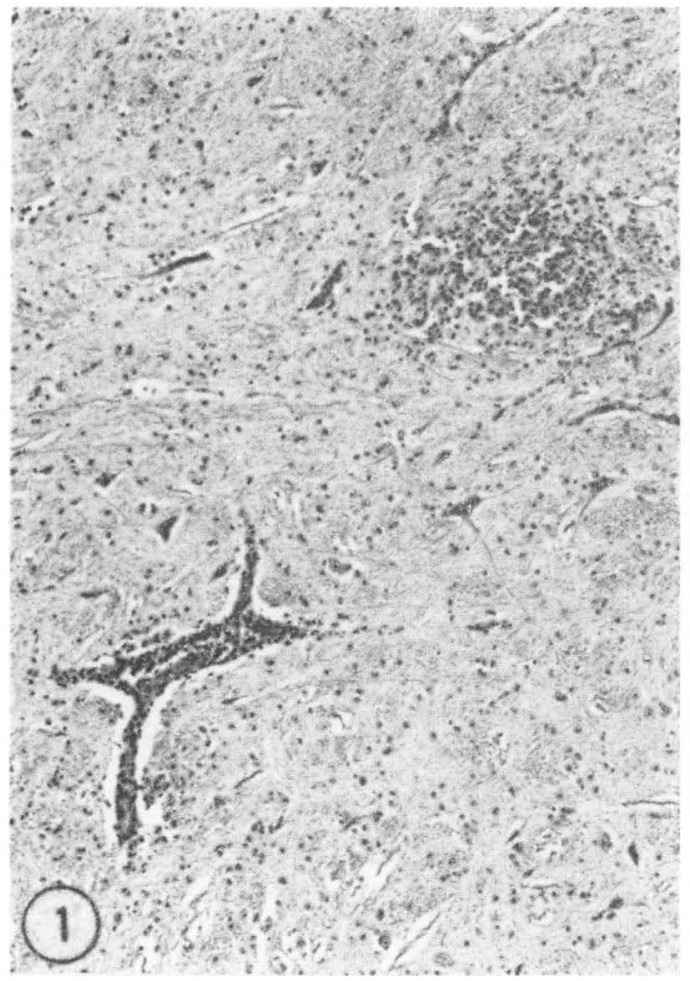

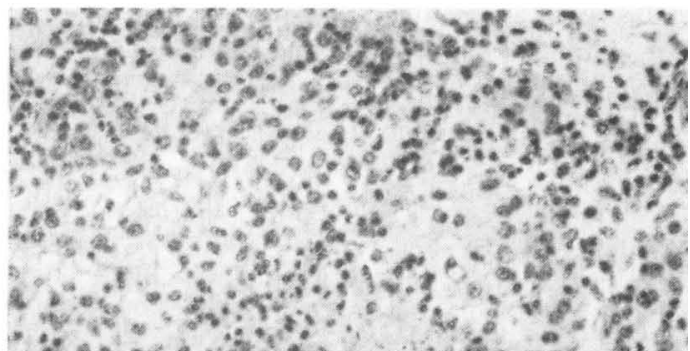

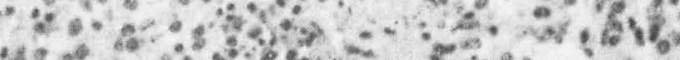

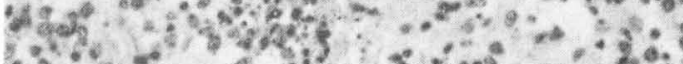

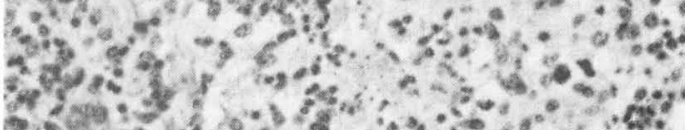

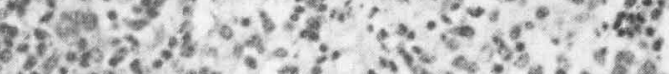
W02.0.

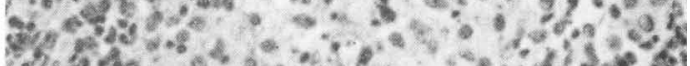
H.

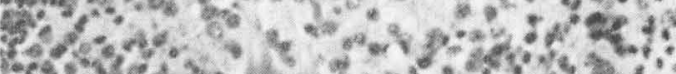

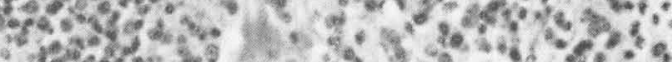

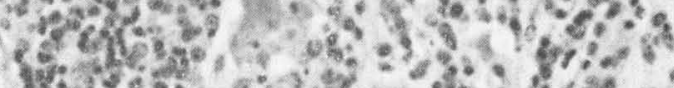

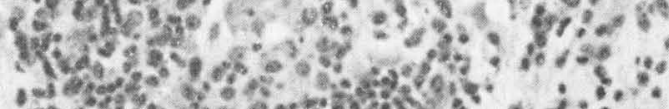
(2) 3 .

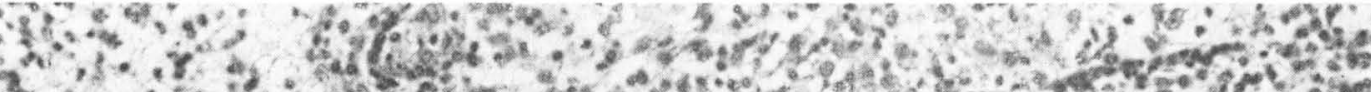

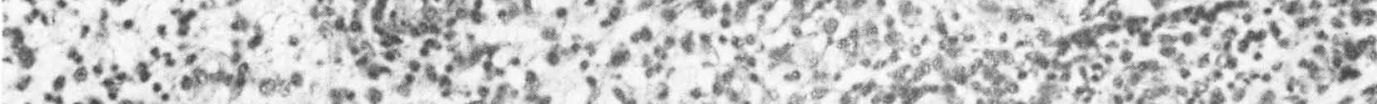

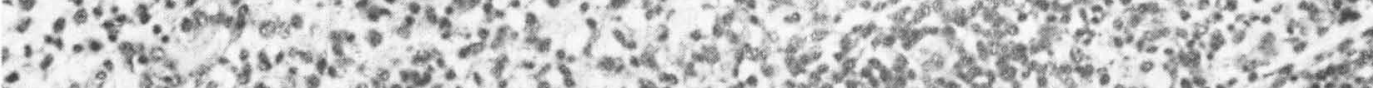
$6 \% 2=0 \%$. $13,-30$ :

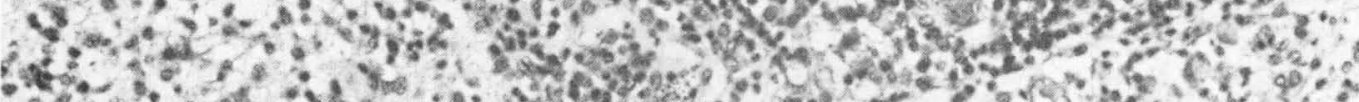

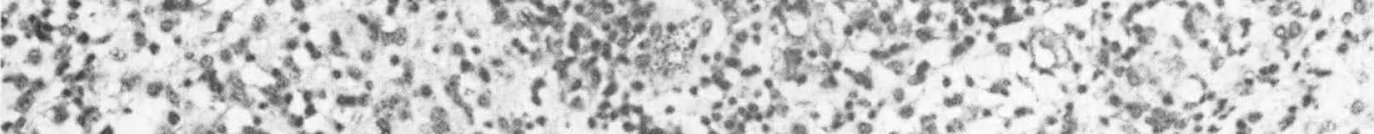

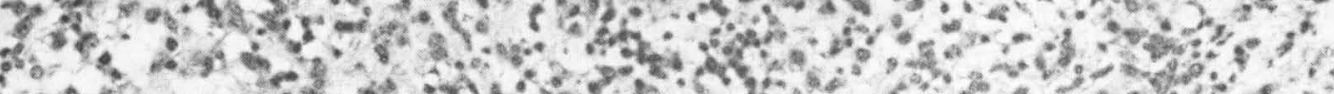

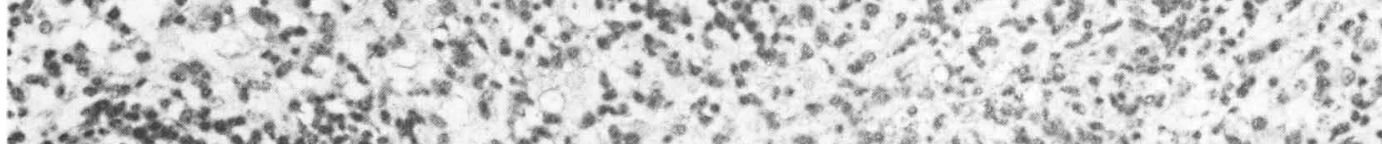

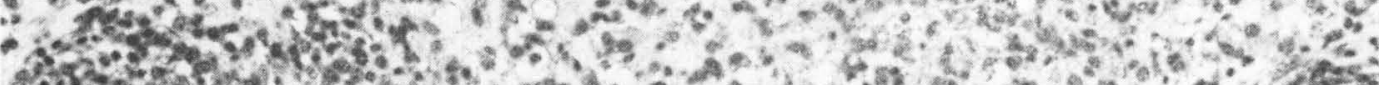

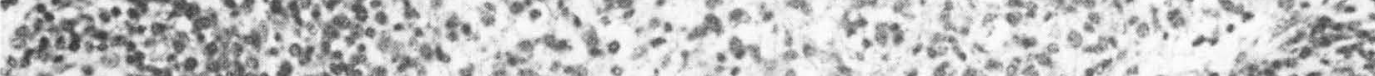

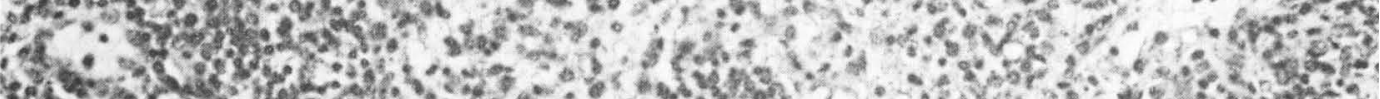

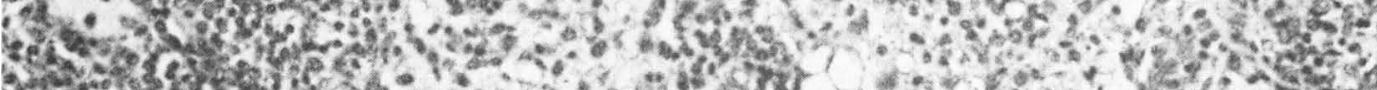

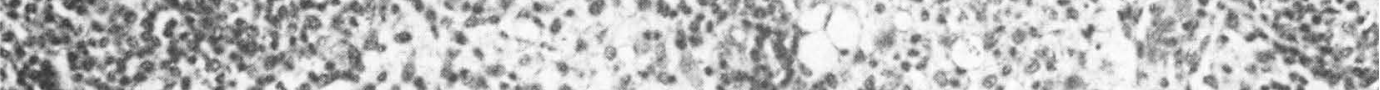

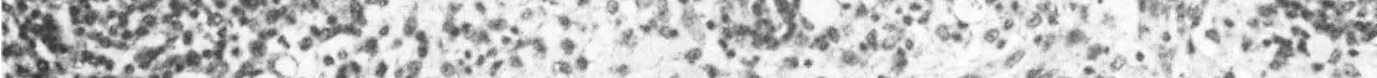

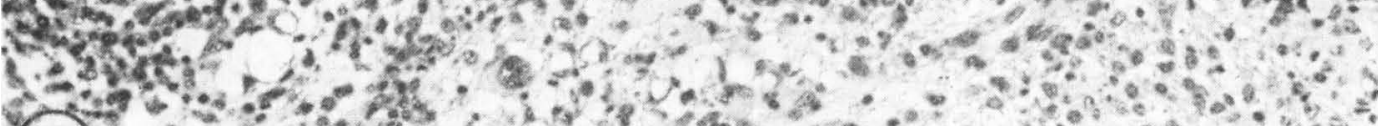

(3) $=0$ a 


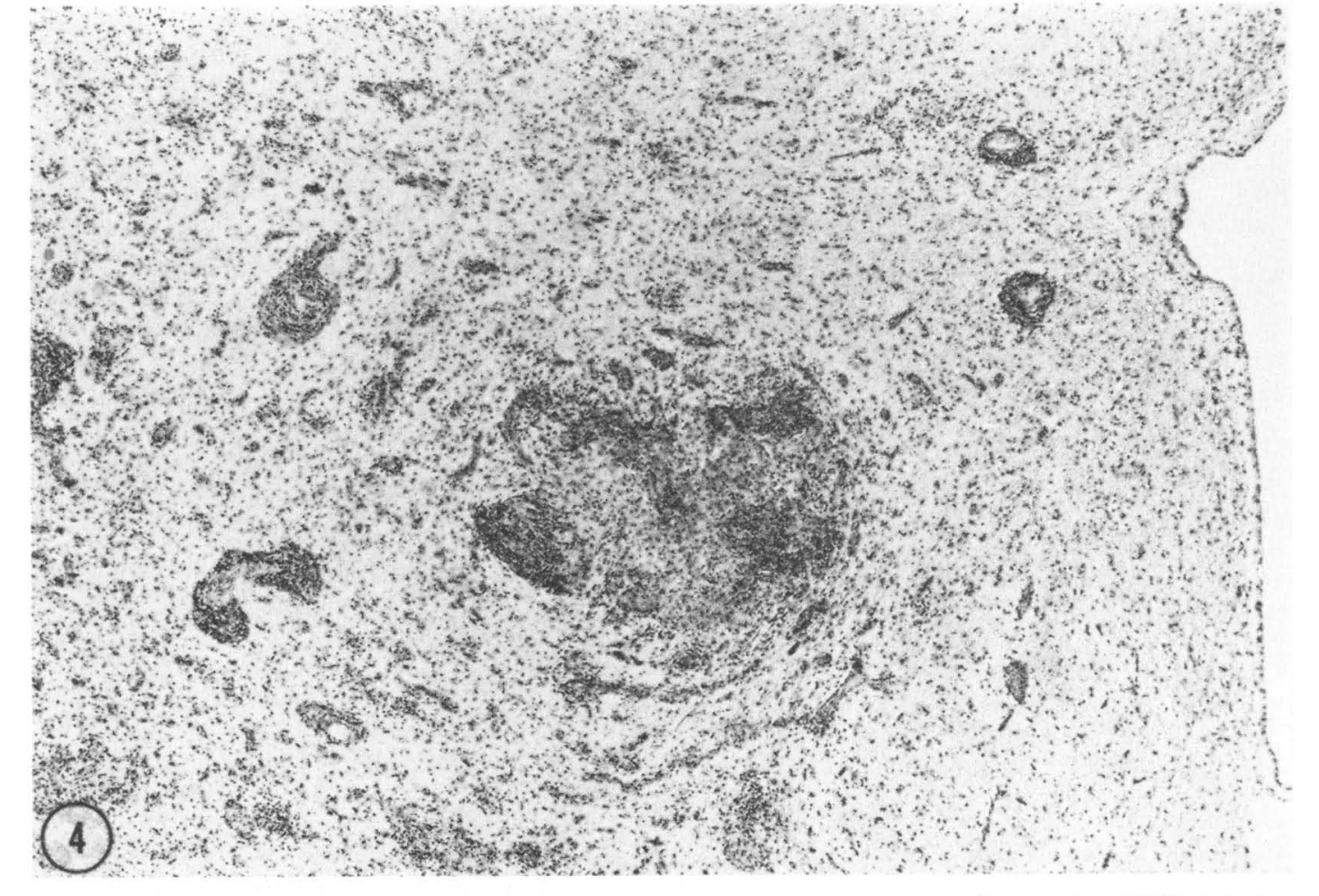

4.5.

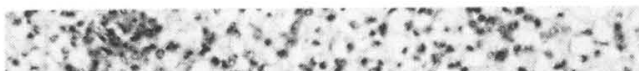

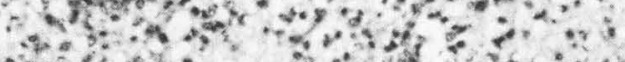

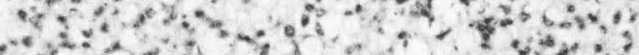

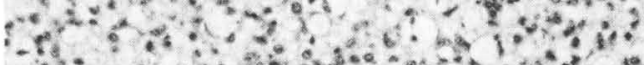

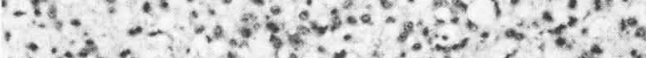

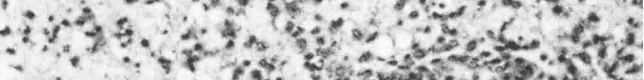

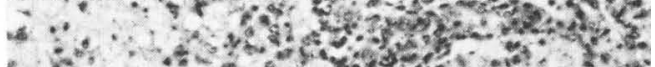

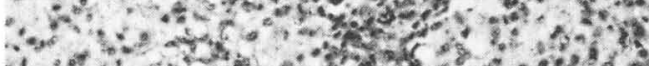

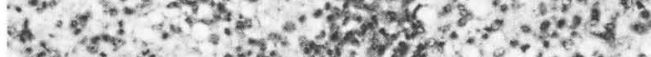

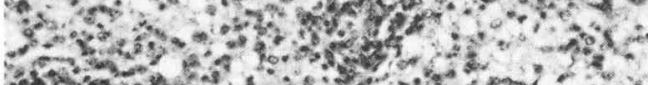

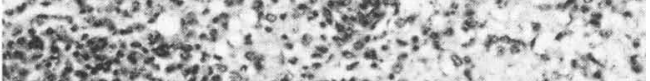

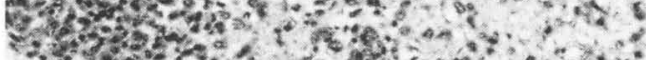

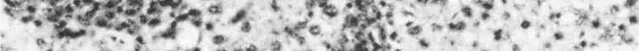

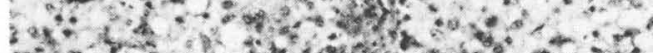

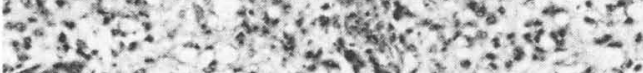

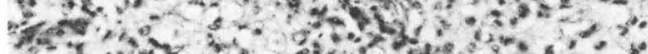

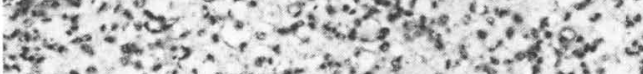

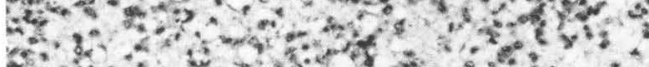

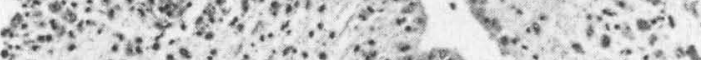

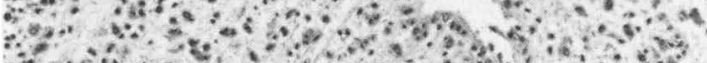

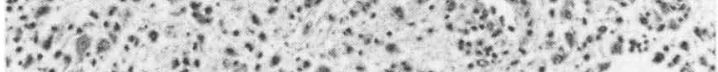

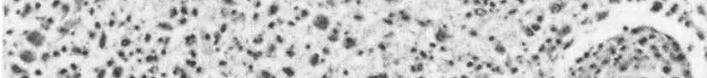

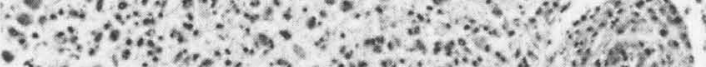

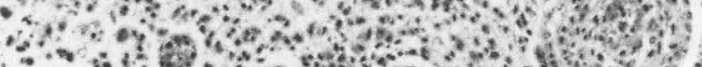

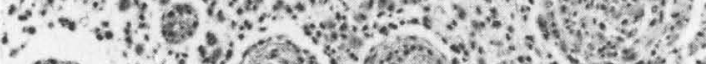

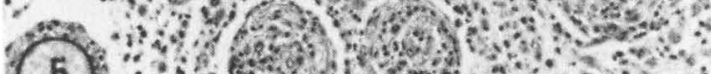

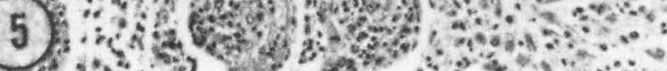

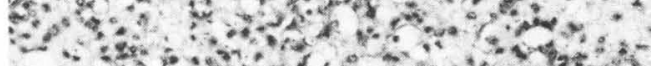

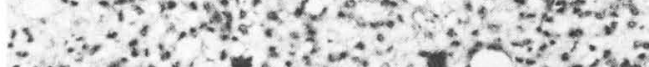

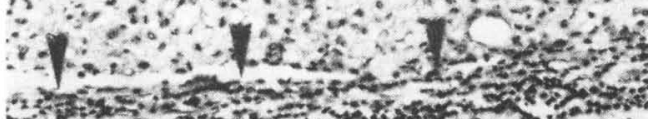
wask

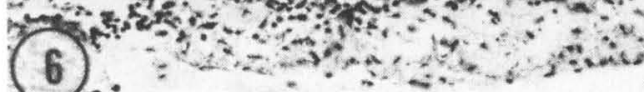




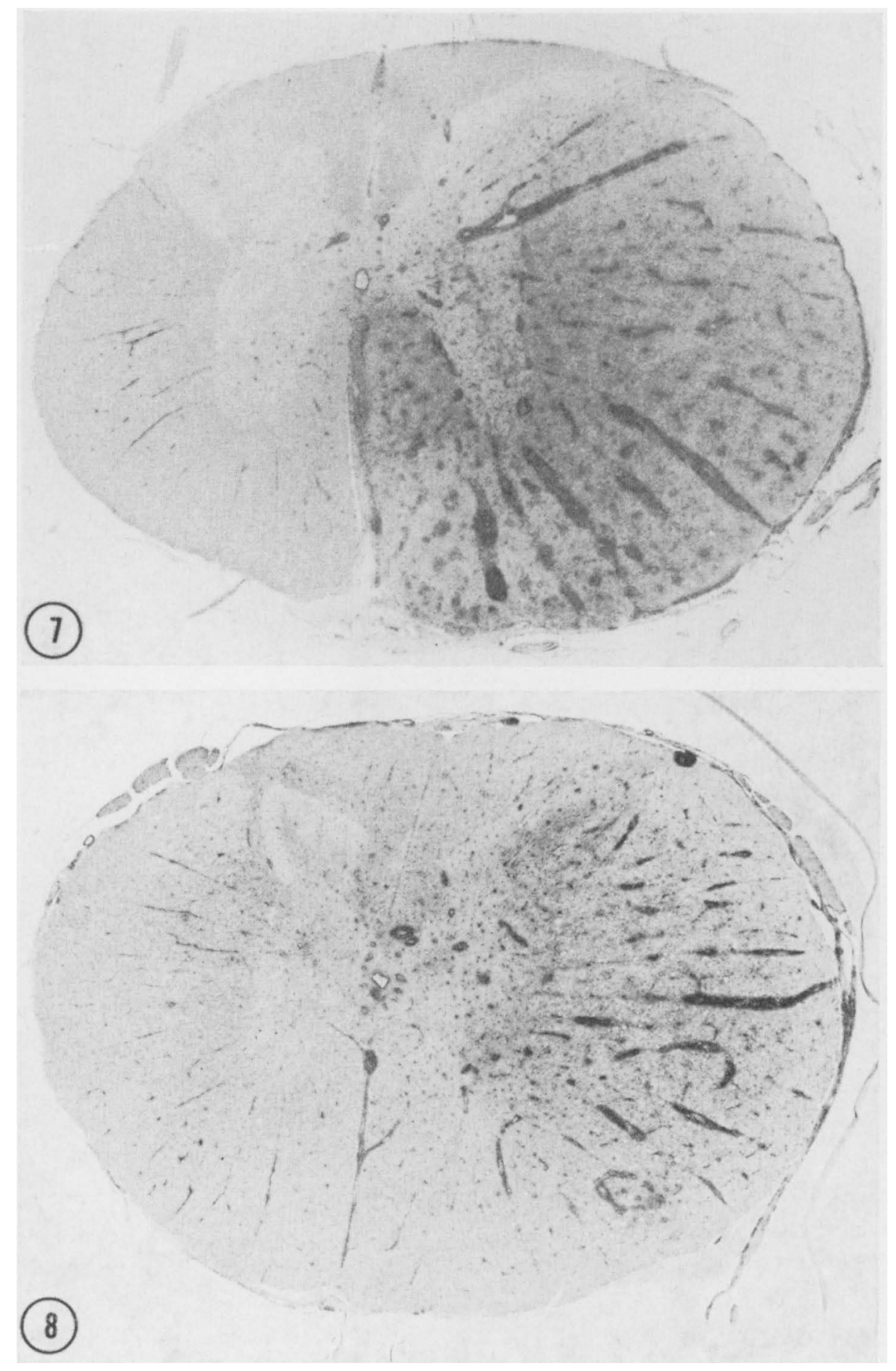



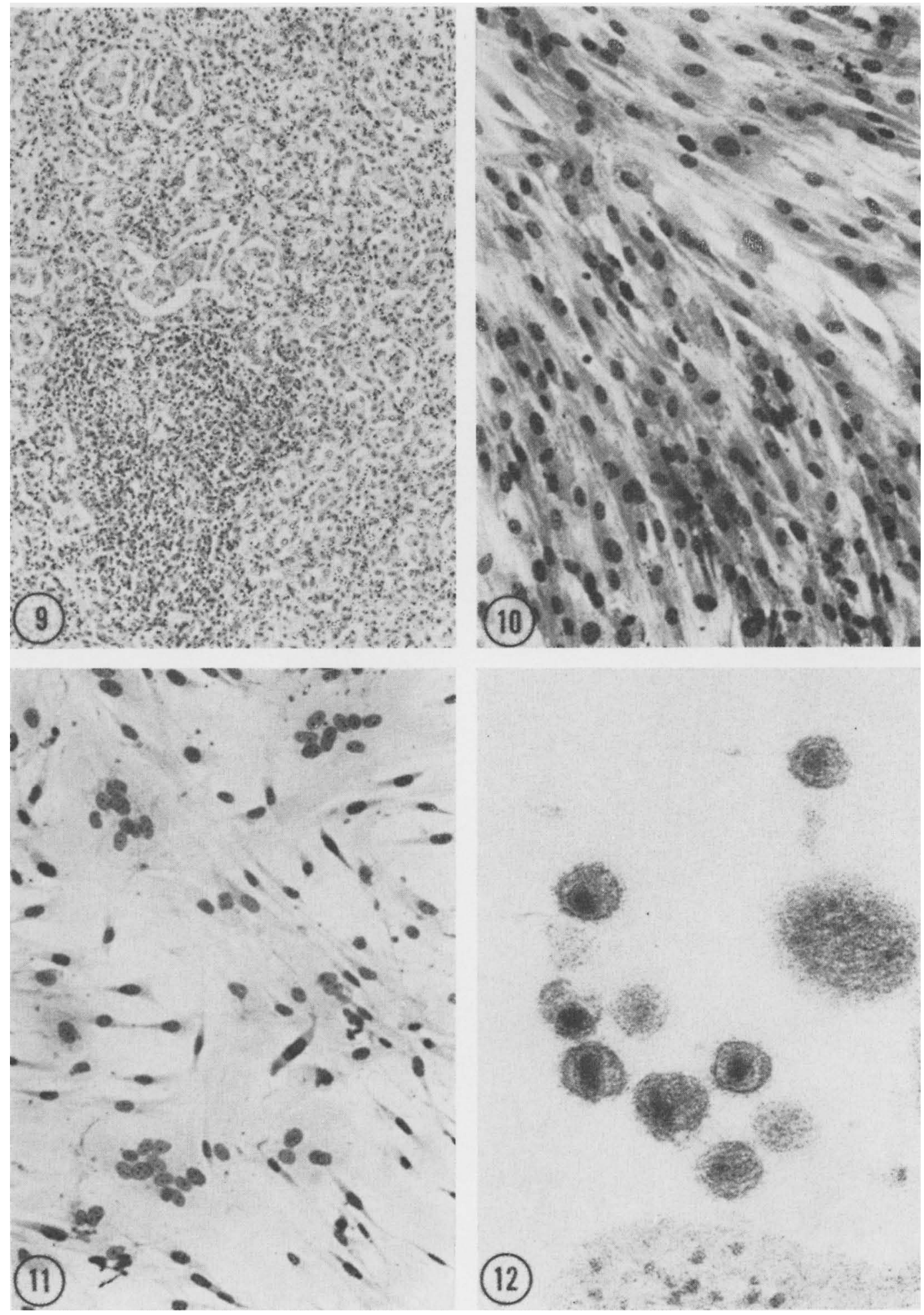


\section{Biochemical and hematological findings}

Biochemical and hematological values were within normal limits with the exception of the total leukocyte counts of 2 animals; one animal had a lymphocytosis $\left(20,405 \times 10^{8} / 1\right)$ and the other a leukocytosis $\left(14,400 \times 10^{8} / 1\right)$.

\section{Pathology of naturally infected goats}

Macroscopical changes were minimal and limited to the lungs and the central nervous system. The lungs of 5 animals did not collapse as completely as normal lungs and showed diffusely demarcated greyish-brown areas. These pneumonic areas were visible both on the pleural surface and throughout the parenchyma. Bilateral fibrinous pleuritis was seen in 2 animals.

Focal light-brown discolorations were sometimes seen in the white matter of the brain and spinal cord. Up to half of the cross-sectional area of the spinal cord could be affected for a length of $4-5 \mathrm{~cm}$.

The character of histopathological changes of the central nervous system were the same in all goats. The initial changes were small perivascular inflammatory foci and small glial nodules, which were independent of perivascular inflammatory infiltrates composed of symphocytes, macrophages and plasma cells (Fig. 1). The nodules were composed of lymphocytes, macrophages, plasma cells and glial cells, mainly astrocytes. In cases of more advanced inflammatory reaction these nodules exhibited central necroses with a breakdown of myelin and axons (Fig. 2). In larger necrotic areas extensive destruction of white matter took place with perivascular accumulation of mononuclear cells, macrophages and loss of myelin. Parallel to the development of these local processes, malacia and a diffuse invasion of the parenchyma by inflammatory cells as well as the perivascular infiltration became more prominent (Fig. 3). Mineralization of necrotic tissue was seen in 2 cases.

The sites of predilection for early lesions were around and close to the ventricular system (Fig. 4). The white matter of the occipital lobe was commonly involved; this was due to the extension of subependymal inflammation. The same extension of periventricular and periaqueductal changes was observed in the mesencephalon, cerebellum, pons and medulla. Pathological changes were commonly observed in the basal ganglia and thala- 
mus in the form of perivascular infiltrations and diffuse inflammatory cell response. The cerebral and cerebellar cortices were seldomly affected with the exception of an extension from overlying meningitis or from lesions in the underlying white matter.

The choroid plexus of the lateral, third and fourth ventricles was frequently inflamed. Meningitis was a constant finding and varied in severity and extent. The leptomeninges were infiltrated by patched areas of mononuclear cells, chiefly lymphocytes. No lesions were observed in the sciatic nerves, optic nerves or eyes.

Lesions of the spinal cord were recognized in all goats. The distribution of inflammatory changes was always concentrated to areas surrounding the central canal and generally found at the cervical, thoracic and lumbar levels of the cord (Fig. 5). The character of inflammatory changes was similar to that of the brain. Both white and grey matter was involved and confluent inflammatory foci apparently radiated from the central canal (Figs. 6 and 7).

Interstitial pneumonia was characterized by mononuclear cell infiltration, hyperemia and hyperplasia of pulmonary lymphoid tissue. The mononuclear cells were composed of macrophages, lymphocytes and plasma cells. There was considerable variation in the severity of pneumonia from animal to animal. In severe cases the thickenings of interalveolar septa with mononuclear cells almost obliterated the alveoli (Fig. 9).

\section{Cell culture findings}

Light microscopic examination of CP cells prepared from sick goats showed a pattern of fibroblastic-like cells with concomitant irregular development in the cell layer of foci of multinucleated giant cells (syncytia) (Fig. 11). In contrast, CP cells from healthy animals showed only fibroblastic cells grown in a regular texture (Fig. 10).

Fig. 12 demonstrates that in electron microscopic pictures of the syncytia harbouring CP cells, clusters of particles with electron-dense cores were seen in the intercellular space. These particles had an average diameter of $80 \mathrm{~nm}$. Numerous pleomorphic particles were also seen along the cell side together with a variable number of buds. The electrondense core particles had a morphologic resemblance to mature C-type particles of retroviruses. We could identify particles of the same morphology in CP cells prepared from 5 diseased goats out of 6 . 


\section{Serological tests}

A preliminary serological test was performed to estimate the frequency of GVV infection in goat herds.

The results of a CF test demonstrating SVV specific antibodies are given in Table 1 . The 7 herds which included some CF seropositive animals also had cases of nervous disorder. Correlation was also observed for the $4 \mathrm{CF}$ seronegative herds where no affected goats were reported; these 11 herds did not have any contact with each other. This indicates that a correlation may exist at the head level between cases of nervous disorder and the presence of seropositive sera.

T a b l e 1. Complement fixing antibodies to sheep visna virus in sera of goat herds with and without cases of nervous disorder.

\begin{tabular}{rrcc}
\hline Herd & Goats $^{1}$ & Positive sera $^{2}$ & Paralysis $^{3}$ \\
\hline 1 & 50 & $5 / 6$ & + \\
2 & 40 & $0 / 6$ & - \\
3 & 50 & $1 / 3$ & + \\
4 & 20 & $0 / 3$ & - \\
5 & 40 & $0 / 4$ & - \\
6 & 35 & $2 / 8$ & + \\
7 & 20 & $1 / 4$ & + \\
8 & 100 & $1 / 4$ & + \\
9 & 35 & $1 / 6$ & - \\
10 & 25 & $0 / 5$ & + \\
\hline
\end{tabular}

1 total number of goats in the herd at the time of serum collection.

2 figures give the number of positive samples over the number of samples tested.

${ }^{3}$ paralysis present $(+)$ or absent (-).

For further confirmation and for study of the relative sensitivity of some serological methods we collected sera from 5 goat herds where paretic goats had previously been observed. These sera were then tested for the presence of CF antibodies, precipitating antibodies against SVV and GVV and with the ELISA technique using GVV antigen (Table 2). It was calculated from the results that $80 \%$ of the examined animals were infected with GVV. It also appeared that ELISA was the most sensitive technique and that $\mathrm{CF}$ was less sensitive than immunodiffusion and ELISA. 
T a b le 2. A comparison between results obtained from sera in 5 goat herds by complement fixation (CP), immunodiffusion (ID) and ELISA.

\begin{tabular}{clrrr}
\hline \multirow{2}{*}{$\begin{array}{c}\text { Number } \\
\text { of } \\
\text { goats }\end{array}$} & \multicolumn{4}{c}{ Number of positive sera (\%) } \\
\cline { 2 - 5 } & CF-SVV & ID-SVV & ID-GVV & ELISA \\
\hline 46 & $6(13)$ & $18(39)$ & $23(50)$ & $46(100)$ \\
34 & $8(24)$ & $11(32)$ & $19(56)$ & $30(88)$ \\
10 & ND $^{2}$ & $3(30)$ & $3(30)$ & $7(70)$ \\
10 & ND & $5(50)$ & $8(80)$ & $9(90)$ \\
11 & ND & $2(21)$ & $3(27)$ & $6(55)$ \\
\hline
\end{tabular}

1 SVV and GVV were used as antigen as indicated.

2 not determined.

We also tested 19 serum samples collected from 2 sheep herds which grazed together with goats that were seropositive in the immunodiffusion test for GVV or SVV antigen, and none of the sheep sera reacted positively against either SVV or GVV in the immunodiffusion test.

\section{Experimental infection}

An experimental infection with pelleted virus from goat CP cultures was performed to establish the infectious nature of the virus. Two goat kids were infected intracerebrally and one intranasally. The intranasally infected kid showed clinical signs of visna after 3 months of incubation. The topography of histopathological changes were similar to those in natural infection. Perivascular infiltrates and small glial nodules surrounded the ventricular system of the brain. The pathological changes of the spinal cord were more prominent and were observed in the cervical, thoracic and lumbar regions. Necroses with glial proliferations and perivascular infiltrates were recognized in these regions (Fig. 8).

Intracerebrally infected goats showed no sign of clinical disease during the experimental periods of 4 and 6 months, respectively. Only slight CNS lesions were registered at histological examination of the 2 goats. A few perivascular infiltrates were found in the periventricular white matter of the occipital lobes. The same type of changes were also seen in the thalamus, pons and medulla. 
Serological tests were performed on serum samples collected at 4-week intervals. In the immunodiffusion test, none of these sera reacted against GVV. With the indirect ELISA technique, a positive reaction was recorded when using either SVV og GVV. Two of the animals showed immediate increased serum titers which finally exceeded the pre-infectious background values 4 and 5 times respectively. The other animal had moderate increased titers over the background and reached a plateau after 8 weeks.

\section{DISCUSSION}

The results of our investigation show that visna occurs in Swedish goat herds and that a retrovirus, GVV, obtained from CP cells of goats with this disease can reproduce the lesions of meningoencephalomyelitis in goat kids. Morphological changes in the central nervous system explain the clinical signs of ataxia loss of balance, flexion of the fetlock joints, trembling of the lips, paresis etc. The histopathologic appearance and the topographic distribution of the CNS lesions of the goats are similar to those of the visna in sheep (Sigurdsson et al. 1962). Disseminated perivenous mononuclear cell reaction and histiocytic microglial cell response, accompanied by a variable destruction of myelin, are characteristic changes in visna.

This study shows that the inflammation apparently spreads from the periventricular localization to the adjacent white and grey matter of the brain and spinal cord (Figs. 4, 5 and 7). Thus, the deep part of the cerebral white matter is more frequently involved than the white matter of the cerebral gyri. Dahme et al. (1973) made the same observations and described the CNS lesions as granulomatous meningoencephalomyelitis.

The clinical differentiation of visna from other conditions in goats that cause clinical signs, referable to either the musculoskeletal or the central nervous system, may sometimes be difficult. Listeriosis, traumatic nerve lesions, white muscle disease, enterotoxemia, cerebrocortical necrosis (CCN), hypocalcemia, hypomagnesemia and toxoplasmosis may in some phases show similar clinical signs.

However, most of these diseases have a more sudden onset and usually terminate the life of the animal within a few hours or days, whereas in goat visna the interval from the onset to 
prostration and consequently, sacrifice is usually weeks or months. In addition, other diseases than visna could be excluded from a pathological point of view.

At electron microscopical examination of the choroid cell cultures, we observed particles which have a dense corestructure and a surrounding membrane structure (Fig. 12). This morphology is typical for C-type retrovirus particles, e.g. in vitro-grown visna virus in sheep CP cells. The same observation was made by Weinhold (1974), and recently by Cork \& Narayan (1980) and Crawford et al. (1980 a, b) who described a caprine-arthritisencephalitis-virus (CAEV) in goats. The visna-like disease in the goats, the presence of a retrovirus particle and the demonstration of SVV-specific antibodies in some of the goat sera, suggest that GVV is closely related to SVV. A more thorough biochemical characterization of GVV has confirmed its classification as a retrovirus and its antigenic relationship to SVV (Sundquist 1980). A similar relationship between CAEV and SVV has recently been reported by Narayan et al. (1980).

Although the experimental infection was performed on a small number of animals, the results clearly indicate that an infectious virus was produced from the persistently infected CP cells. The virus infection in one goat induced a disease similar to natural goat visna (Fig. 8, and in the two other kids histopathological changes resembling early lesions seen in experimental SVV infection in lambs (Pálsson et al. 1977). Furthermore, after infection the goats produced antibodies to SVV which indicates a close antigenic relationship between GVV and SVV.

In Icelandic sheep, visna was a rare natural disease whereas maedi, caused by the same virus (Sigurdardóttir \& Thormar 1964, Weiss et al. 1977) was far more common (Pálsson 1976). We observed no clinical signs of maedi in the goats affected by visna and maedi-like interstitial pneumonia was identified at post-mortem examination (Fig. 9). It should be noticed that a few cases of maedi in goats were observed in Denmark (HoffJorgensen 1980).

Cork et al. (1974 a, b) published the first reports from the USA on viral leukoencephalomyelitis (VLG) in goats. The disease was then reported from Australia (O'Sullivan et al. 1978) and Switzerland (Fatzer 1979). It is clinically manifested by progressive paresis in young goats and is accompanied by lesions morphologically similar to visna in sheep. 
Recently Crawford et al. (1980 a, b) and Adams et al. (1980) found that demyelinating encephalomyelitis in goats was combined with widespread connective tissue changes, affecting several organs but most regularly the joints, tendon sheaths and synovial bursae. In addition to CNS lesions, the pathology included perivascular accumulation of lymphocytes and plasma cells and joint capsular and periarticular collagen necrosis. A retrovirus, caprine arthritis-encephalomyelitis virus (CAEV), was isolated from joints and brains. It is interesting to note that connective tissue CAEV-isolates could only be grown in the synovial cells, thus indicating the existence of CAEV variants with different primary tissue growth specificities. In our goat materal we could not find any signs of connective tissue changes in the joints or other organs. It is suggested that the two goat viruses GVV and CAEV (Narayan et al. 1980) are related to SVV, but they do not seem to give an identical development of the infectious disease in goats. Furthermore, although SVV is antigenically related to GVV, these viruses seem to be associated species, i.e. SVV could not be transmitted to goats (Pétursson 1980). Our serological data suggests that GVV transmission do not occur between goats and sheep.

Preliminary results of $\mathrm{CF}$ tests showing antibodies against sheep visna virus indicate an extensive geographic distribution of the infection in dairy goats in Sweden. The visna infection is serologically confirmed in additional goat herds from other areas where veterinarians have suspected the occurrence of visna. Positive serological tests for visna virus antibodies in goats have been reported from West Germany (Weinhold 1974, Weinhold \& Triemer 1978), Norway (Krogsrud 1980) and Denmark (HoffJørgensen 1980).

The results of the present study show that the Swedish goat population is infected with a retrovirus, goat visna virus, which is the agent of a disease similar to visna in sheep. It is concluded that the visna infection might be widespread in Sweden and further studes should be undertaken to record a possible future spreading of the disease in goat herds.

\section{ACKNOWLEDGEMENTS}

The authors are grateful to $\mathrm{Dr} \mathrm{Z}$. Dinter for valuable discussions and to $\mathrm{Dr} \mathrm{K}$. Olsson for skilful operation of the kids. The work was supported by the Swedish Council for Forestry and Agriculture Research. 


\section{REFERENCES}

Adams, D. S., T. B. Crawford \& P. Klevjer-Anderson: A pathogenetic study of the early connective tissue lesions of viral caprine arthritis-encephalitis. Amer. J. Path. 1980, 99, 257-278.

Cork, L. C., W. J. Hadlow, T. B. Crawford, J. R. Gorham \& R. C. Piper: Infectious leukoencephalomyelitis of young goats. J. infect. Dis. 1974 a, 129, $134-141$.

Cork, L. C., W. J. Hadlow, J. R. Gorham, R. C. Piper \& T. B. Crawford: Pathology of viral leukoencephalomyelitis in goats. Acta neuropath. (Berl.) $1974 \mathrm{~b}, 29,281-292$.

Cork, L. C. \& O. Narayan: The pathogenesis of viral leukoencephalomyelitis-arthritis of goats. I. Persistent viral infection with progressive pathologic changes. Lab. Invest. 1980, 42, 596-602.

Crawford, T. B., D. S. Adams, W. P. Cheevers \& L. C. Cork: Chronic arthritis in goats caused by a retrovirus. Science 1980 a, 207, 997-999.

Crawford, T. B., D. S. Adams, R. D. Sande, J. R. Gorham \& J. B. Henson: The connective tissue component of the caprine arthritisencephalitis syndrome. Amer. J. Path. $1980 \mathrm{~b}, 100,443-454$.

Dahme, R., D. Stavrou, N. Deutschländer, W. Arnold \& E. Kaiser: Klinik und Pathologie einer übertragbaren granulomatösen Meningoencephalomyelitis ( $g$ MEM) bei der Hausziege. (Clinical and pathological findings in a transmissible granulomatous meningoencephalomyelitis in domestic goats). Acta neuropath. (Berl.) $1973,23,59-76$.

Fatzer, R.: Encephalo-Myelitis granulomatosa bei Zicklein in der Schweiz. (Granulomatous encephalomyelitis in goat kids in Switzerland). Schweiz. Arch. Tierheilk. 1979, 171, 329-339.

Griem, W. \& E. Weinhold: Zur Pathologie der Visna der Ziege. (The pathology of visna in goat). Dtsch. tierärztl. Wschr. 1975, 82, $396-400$.

Haase, A. T.: The slow infection caused by visna virus. Curr. Top. Microbiol. Immunol. 1975, 72, 101-156.

Hammarberg, K.-E.: Getter (Goats). Svensk Vet.-tidn. 1978, 30, 45-55.

Hoff-Jørgensen, R.: Personal communication 1980.

Krogsrud, J.: Personal communication 1980.

Narayan, O., J. E. Clements, J. D. Strandberg, L. C. Cork \& D. E. Griffin: Biology characterization of the virus causing leukoencephalitis and arthritis in goats. J. gen. Virol. in press.

O'Sullivan, B. M., F. W. Eaves, S. A. Baxendell \& K. J. Rowan: Leucoencephalomyelitis of goat kids. Aust. vet. J. 1978, 54, 479-483.

Pálsson, P. A.: Maedi and visna in sheep. In Kimberlin, R. H. (ed.): Slow virus Diseases of Animals and Man. North-Holland Publ. Co., Amsterdam and Oxford, 1976, p. 17-43.

Pálsson, P. A., G. Georgsson, G. Pétursson \& N. Nathanson: Experimental visna in Islandic lambs. Acta vet. scand. 1977, 18, 122128. 
Pétursson, G.: Personal communication 1980.

Sigurdardottir, B. \& H. Thormar: Isolation of a viral agent from the lungs of sheep affected with maedi. J. infect. Dis. 1964, 114, $55-60$.

Sigurdsson, B.: Observations on three slow infections of sheep. Brit. vet. J. 1954, 110, 225-270.

Sigurdsson, B.: Atypically slow infectious diseases. In Livre Jubilaire du Dr. Ludo van Bogaert, Brussels. Acta Medica Belgica 1962, 738-753.

Sigurdsson, B. \& P. A. Pálsson: Visna of sheep. A slow demyelinating infection. Brit. J. exp. Path. 1958, 39, 519-528.

Sigurdsson, B., P. A. Pálsson \& H. Grimsson: Visna, a demyelinating transmissible disease of sheep. J. Neuropath. exp. Neurol. 1957, $16,389-403$.

Stavrou, D., N. Deutschländer \& E. Dahme: Granulomatous encephalomyelitis in goats. J. comp. Path. 1969, 79, 393-396.

Sundquist, B.: Goat visna virus: Isolation of retrovirus related to sheep visna virus. Submitted for publication, 1980.

Sundquist, B. \& E. Larner: Phosphoroformate inhibition of visna virus replication. J. Virol. 1979, 30, 847-851.

Voller, A., D. Bidwell \& A. Bartlell: Microplate enzyme immunoassay for the immunodiagnosis of virus infections. In Rose, N. R. and H. Friedman (ed.): Manual of Clinical Immunology. American Society for Microbiology, Washington D.C. 1976, p. 506-512.

Weinhold, E.: Visna-virus-ähnliche Partikel in der Kultur von Plexus choroideus-Zellen einer Ziege mit Visna-Symptomen. (Particles siminal to visna virus in the culture of choroid plexus cells of a goat with symptoms of visna). Zbl. Vet. Med. B. 1974, 21, $32-36$.

Weinhold, E. \& B. Triemer: Visna bei der Ziege. (Visna in goat). Zbl. Vet. Med. B. 1978, 25, 525-538.

Weiss, M. J., E. P. Zelon, R. W. Sweet, D. H. Hauter \& S. Spiegelman: Immunological cross-reactions of the major internal protein component from "slow" viruses of sheep. Virology 1977, 76, $851-854$.

\section{SAMMANFATTNING}

Meningoencephalomyelit hos getter förorsakad av visnavirus.

Progressiv pares påvisades hos svenska getter. Symtombilden började med svaghet $i$ bakbenen och utvecklades långsamt under veckor eller månader. Sjukdomsförloppet och de histopatologiska förändringarna $i$ centrala nervsystemet och lungorna var $i$ överensstämmelse med vad som beskrivits'vid visna hos får. i vävnadskulturer av choroidplexusceller från sjuka getter påvisades polykaryocyter. Vid elektronmikroskopisk undersökning iakttogs partiklar, som morfologiskt liknade visnavirus hos får (SVV). Hos getter, som experimentellt 
infekterades med getvisnavirus (GVV), utvecklades skador i centrala nervsystemet av samma utseende som vid visna. De blev serologiskt positiva mot SVV. Serologisk undersökning med komplementfixeringstest av getter från elva besättningar visade att det föreligger en korrelation mellan förekomst av positiva testresultat och sjukdomsfall i besätningarna. Med ELISA visades att i medeltal 80 procent av getterna i fem testade besätningar var serologiskt positiva mot GVV.

(Received March 2, 1981).

Reprints may be requested from: Lennart Jönsson, the Department of Pathology, Faculty of Veterinary Medicine, Swedish University of Agricultural Sciences, S-750 07 Uppsala, Sweden. 